Creative Commons User License: CC BY-NC-ND

Abstracted by: EBSCOhost, Electronic Journals Service (EJS),

Google Scholar, Journal Seek, Scientific Commons,

Food and Agricultural Organization (FAO), CABI and Scopus
Journal of Agricultural Extension

Vol. 25 (2) April, 2021

ISSN(e): 24086851; ISSN(Print); 1119944X

http://journal.aesonnigeria.org

http://www.ajol.info/index.php/jae

Email: editorinchief@aesonnigeria.org

Reliability of the Agricultural Extension and Technological Services among Rice Farmers in the Rural Areas of Tanzania

https://dx.doi.org/10.4314/jae.v25i2.2

\author{
Peter, D. Kulyakwave \\ Department of Agriculture and Livestock, National Service Headquarters \\ Box 2963. Dodoma, Tanzania. \\ Presently at the Agricultural Information Institute, Chinese Academy of Agricultural Sciences, \\ 100081 Beijing, China. Email: pkulyakwave822@yahoo.com Phone:+255767761133 \\ Corresponding author
}

\title{
Shiwei. Xu
}

Agricultural Information Institute, Chinese Academy of Agricultural Sciences, 100081 Beijing,

China. Email: xushiwei@caas.cn Phone: +8613601119952

\section{Wen Yu}

Agricultural Information Institute, Chinese Academy of Agricultural Sciences, 100081 Beijing, China Email: yuwen@caas.cn Phone: +8613581627695

\section{Sar Sary}

Agricultural Information Institute, Chinese Academy of Agricultural Sciences, 100081 Beijing, China Email: sarsary@yahoo.com Phone: +8618513244283

\section{Muyobozi S}

Agricultural Information Institute, Chinese Academy of Agricultural Sciences, 100081 Beijing, China Email: muyobozi2016@issacad.pku.edu.cn Phone: +86501994475

\section{Abstract}

This study provided insights into the availability and use of agricultural information by small scale farmers in the Mbeya Region of Tanzania. The research used structured questionnaires to interview 240 rice farmers in the Mbeya region. The findings revealed that farmers accessed agricultural information from various agents including local government extension staff, neighbors and friends, advertisements, electronic media including the internet, television, radio, and other channels. The identified technological information application methods included by lectures, field demonstrations, exposure visits to various places, and printed production. The majority of farmers perceived to have dissatisfied (43\%), strongly dissatisfied (25\%), strongly satisfied (20\%), satisfied (8\%), and no opinions (4\%) concerning accessibility to agricultural information and technological services. The majority of farmers claimed that both agricultural information and technological communication are strongly needed for agricultural performance. The study suggests that government and non-government organizations should collaborate to bridge the existing information-sharing gap between farmers and information providers.

Keywords: extension communication, technological information, rural areas, rice farmers, Tanzania. 
Creative Commons User License: CC BY-NC-ND

Abstracted by: EBSCOhost, Electronic Journals Service (EJS),

Google Scholar, Journal Seek, Scientific Commons,

Food and Agricultural Organization (FAO), CABI and Scopus

http://eoi.citefactor.org/10.11226/v25i2
Journal of Agricultural Extension

Vol. 25 (2) April, 2021

ISSN(e): 24086851; ISSN(Print); 1119944X

http://journal.aesonnigeria.org

http://www.ajol.info/index.php/jae

Email: editorinchief@aesonnigeria.org

\section{Introduction}

The accessibility to proper information and technological exchange in agricultural sector development enhance farming productivity as well as improving the survival of human beings (lliyas, 2015). Accessibility also creates an enabling environment for better utilization of the various agricultural technologies. The information shared by the backward and forward linkage helps to provide relevant communication required by value chain players such as producers, inputs suppliers, marketers, and consumers. Modern agricultural practices require farmers, governments, and other stakeholders to invest in updated information technology (Moshi and Isinika, 2016). Additionally, under the new technological advancements, the agriculture industry is entirely driven by the information sector. Today's production decisions by farmers originate from reliable agricultural extension and technological information sources. The invention of sophisticated devices such as the Global Positioning System, mobile phones, internet, remote sensing, drones, and other equipment including machinery facilitates reliable information sharing (Yaseen et al., 2016).

In developing countries, crop producers particularly rice producers require various technical information for their farming processes. It includes all the necessary information required before planting, during production, and also after harvesting. Nevertheless, the accessibility, availability, and reliability of the respective information are among the noticeable challenges obstructing small scale producers (Msoffe and Ngulube, 2017). The prominent challenges include failure to access reliable and timely information required for production and market decision. Others include crop information, management practices, and production techniques (Temba et al., 2016). Prudent utilization of new information technology in agricultural production significantly reduces associated production costs and at the same time increasing productivity and efficiency (Schirone, 2016). Strengthening information accessibility boosts socio-economic development at the micro-level and boosts the country's GDP through an organized agribusiness practice. Additionally, the smooth utilization of agricultural information helps in the adoption of new agricultural technology (Asongu and Asongu, 2018). The prevailing poor information knowledge 
Creative Commons User License: CC BY-NC-ND

Abstracted by: EBSCOhost, Electronic Journals Service (EJS),

Google Scholar, Journal Seek, Scientific Commons,

Food and Agricultural Organization (FAO), CABI and Scopus
Journal of Agricultural Extension

Vol. 25 (2) April, 2021

ISSN(e): 24086851; ISSN(Print); 1119944X

http://journal.aesonnigeria.org

http://www.ajol.info/index.php/jae

Email: editorinchief@aesonnigeria.org

sharing and the lack of developed infrastructure contribute to slowing agricultural development in the developing countries. The report shows that farmers with better access to extension and technological services accrue relatively high revenue and profit than their counterparts (Aldosari et al., 2017). This indicates that there is a need to improve access to information and technological communication in the agricultural sector which would subsequently improve agricultural production and marketing (Ase et al., 2017). Moreover, information utilization by rice farmers depends on the trust and reliability of the perceived information (Muema et al., 2018).

In Tanzania agriculture is considered the mainstay of the country's development. Its share of the country's GDP accounts for above 29\% (Tanzania Economic Outlook, 2016). It is predominantly operated by mainly smallholders (above $80 \%$ ) dwelling in the rural areas and practicing both crop production and livestock keeping (Kulyakwave, $\mathrm{Xu}$, and $\mathrm{Yu}, 2019$ ). Besides this, the majority of the farmers use rudimentary farming equipment and application methods as well as poor infrastructure, thus creating a wide gap in terms of information dissemination. Lack of timely agricultural information and technological practices create challenges to small scale farmers. At the same time, the available local extension officers are very few to cover the extremely diversified farmers. Their small number and lack of up to date information deprive farmers of information and resources pertaining to agricultural management. The majority of the local extension staff rely on conventional methods of information delivery, training, and assistance to farmers while the application of modern and innovative technology is very limited (Kulyakwave, $\mathrm{Xu}$, and $\mathrm{Yu}, 2019$ ). Therefore, the current study focused on the availability and the use of agricultural information and technological practices to small scale rice farmers in the study region.

\section{Methodology}

The study covered the two districts of Mbarali and Kyela in the Mbeya Region of Tanzania. Mbeya is a region located in the Southern Highlands of Tanzania. 
Creative Commons User License: CC BY-NC-ND

Abstracted by: EBSCOhost, Electronic Journals Service (EJS),

Google Scholar, Journal Seek, Scientific Commons,

Food and Agricultural Organization (FAO), CABI and Scopus

http://eoi.citefactor.org/10.11226/v25i2
Journal of Agricultural Extension

Vol. 25 (2) April, 2021

ISSN(e): 24086851; ISSN(Print); 1119944X

http://journal.aesonnigeria.org

http://www.ajol.info/index.php/jae

Email: editorinchief@aesonnigeria.org

Historically, the region is among the top three regions in terms of rice production in Tanzania. It is potentially crucial to point out that the majority of the populations in the study area are rice growers, and mostly depend on the rainfed rice-ecosystem. However, few farmers use irrigation water to support their farming activities. The multistage sampling approach was used to obtain the required respondents for the study. Firstly, the purposive sampling technique was used to select two wards from each District. Thereafter, 16 villages were purposively selected from the selected wards. A random sampling technique was used to select 240 rice farmers for the face to face interview. Among the selected respondents 122 were male and 118 female. Data collection was carried out by the use of well-structured questionnaires prepared by the researcher. To adhere to time and clarity, a total of 8 research assistants were employed and trained to support the data collection exercise.

The interview focused on general rice management practices by households, types, availability, and accessibility to agricultural extension and technological services. Besides, understanding the need level and degree of satisfaction of the information and technology services consumed by farmers was focused. Besides, focus group discussions were conducted by involving various key personnel including agricultural extension officers, local village leaders, and experienced local individuals from the study area. Albeit the fact that primary data was highly considered for this study, some various secondary data were sourced to understand and relate with the present agricultural practices in the study area.

\section{Results and Discussion.}

\section{Source of Agriculture and Technology Information}

Figure 1 shows that the identified sources of agriculture and technology information were neighbors or friends $(37.9 \%)$, local government extension staff $(22.9 \%)$, agents or dealers $(21.7 \%), \%)$, electronic media $(13.3 \%)$, printed instructions or advertisements (2.5) and others sources (1.7\%). 


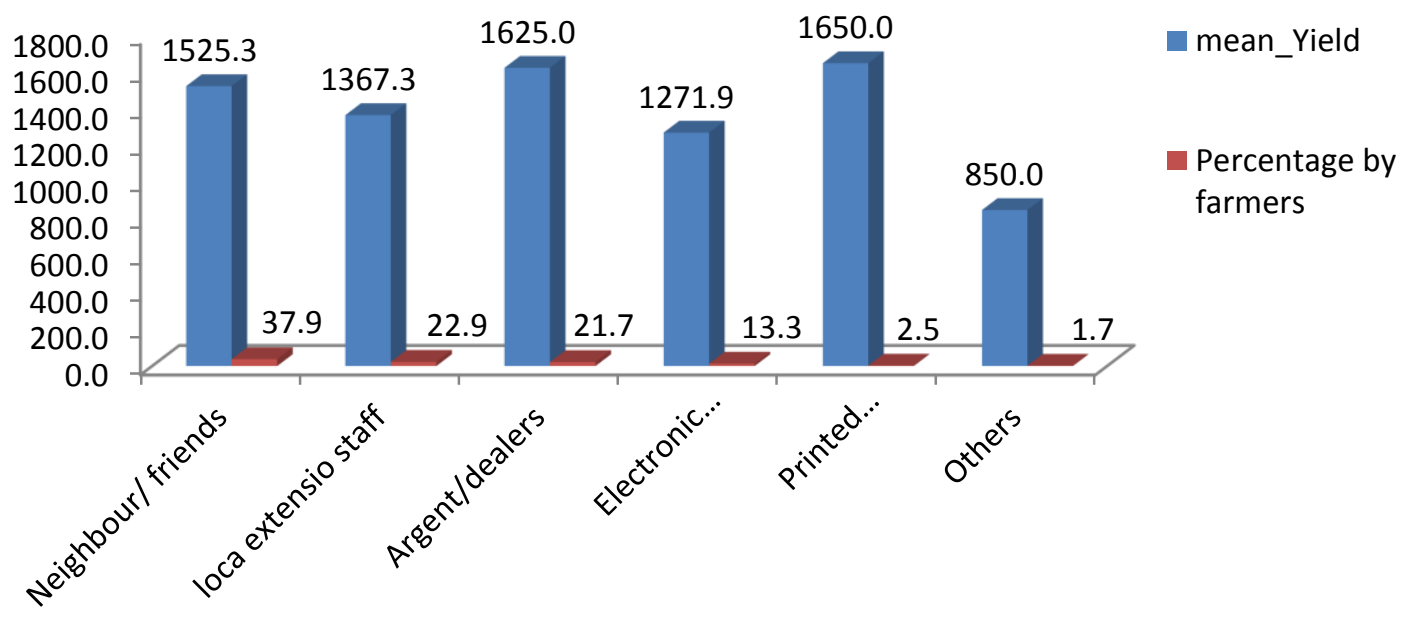

Figure 1: Source of information and technology

Farmers in rural areas have expressed their concern about various sources of agricultural information and technology services. On the other hand, farmers declared having access to the various available means of information. This finding is similar to the findings of Muema et al. (2018) who reported in the rural areas of Kenya. However, the main challenge remains that of information reliability and utilization. The most common information sources in the local environment are from neighbors and friends (Baig et al., 2019).

However, with the increasing diversification in agricultural practice, the sources have been changing from time to time especially with the invention of science and technology in the agricultural sector. This is attributed to the current development of electronic devices such as radio, television, and mobile phones which could be easily accessible to disseminate information from one farmer to another (Yaseen et al., 2016). The methods are contrary to the conventional means of using local government extension officers, although, it is still useful in many rural areas of the developing countries regardless of the myriad challenges (Ashraf et al., 2019). Moreover in some cases, relying on government extension officials has proved an inefficient way of timely information dissemination for the dispersed rural farmers (Khan et al., 2019). The current finding concurs with that of Kansiime et al. (2019) as 
Creative Commons User License: CC BY-NC-ND

Abstracted by: EBSCOhost, Electronic Journals Service (EJS),

Google Scholar, Journal Seek, Scientific Commons,

Food and Agricultural Organization (FAO), CABI and Scopus

http://eoi.citefactor.org/10.11226/v25i2
Journal of Agricultural Extension

Vol. 25 (2) April, 2021

ISSN(e): 24086851; ISSN(Print); 1119944X

http://journal.aesonnigeria.org

http://www.ajol.info/index.php/jae

Email: editorinchief@aesonnigeria.org

they reported that about $73 \%$ of farmers in India obtain agricultural information from their relatives and friends. Based on the current findings, $22.9 \%$ of the smallholder farmers reported having access to information regarding agricultural practices from local government extension officers. This includes agronomic advice, land preparation technicalities, seed availability and use, crop planting calendar, fertilizer availability and application methods, pesticides, and crop variety (Ashraf et al., 2019

Contrary to our findings, a study by Aldosari et al. (2017) reported that in Pakistan most farmers in the rural areas perceive the government extension service staff as big officials who become difficult to approach, especially through mobile phones. Input providers and other dealers within the production and marketing chain are among the important key players for conveying information to farmers. Regardless of the roles played by these agents, farmers claimed that they are unreliable for the fact that they are not well accessible. Some of the information provided by the agents is expensive, and unless farmers are linked or subscribed to the respective groups they won't receive the required information on time (Neha et al., 2018). The evolution of electronic devices such as uses of radio, mobiles, television, global position systems (GPS), use of remote sensing, geographic information systems (GIS) has been useful for agricultural production. Their application in agricultural production systems has been providing required but accurate information to farmers.

A reasonable number $(13.3 \%)$ of the farmers declared to receive information and technological services from the electronic media. For the smallholder rice farmers, the observed challenges include ownership and application of some devices like smartphone mobiles and television. Some farmers possess devices but are limited in terms of applications as the majority could only make and receive calls (Neha et al., 2018 and Khan et al., 2019).

\section{Information Needed by Farmers}

Figure 2 shows farmers' expressions on the type of information and technology services needed for their farming activities. The results depicted on various 
Creative Commons User License: CC BY-NC-ND

Abstracted by: EBSCOhost, Electronic Journals Service (EJS), Google Scholar, Journal Seek, Scientific Commons,

Food and Agricultural Organization (FAO), CABI and Scopus

http://eoi.citefactor.org/10.11226/v25i2
Journal of Agricultural Extension

Vol. 25 (2) April, 2021

ISSN(e): 24086851; ISSN(Print); 1119944X

http://journal.aesonnigeria.org

http://www.ajol.info/index.php/jae

Email: editorinchief@aesonnigeria.org

technological services applied in rice farming include seeds, pesticides, machinery, Integrated Pests Management (IPM), fertilizer, and cultivation methods. As shown in Figure 2 the technological services strongly needed were pesticides $(65 \%)$, seeds $(64 \%)$, fertilizer $(60 \%)$, irrigation technology $(58 \%)$, cultivation technology $(55 \%)$, and machinery (48\%).

\section{Information needs level by farmers}

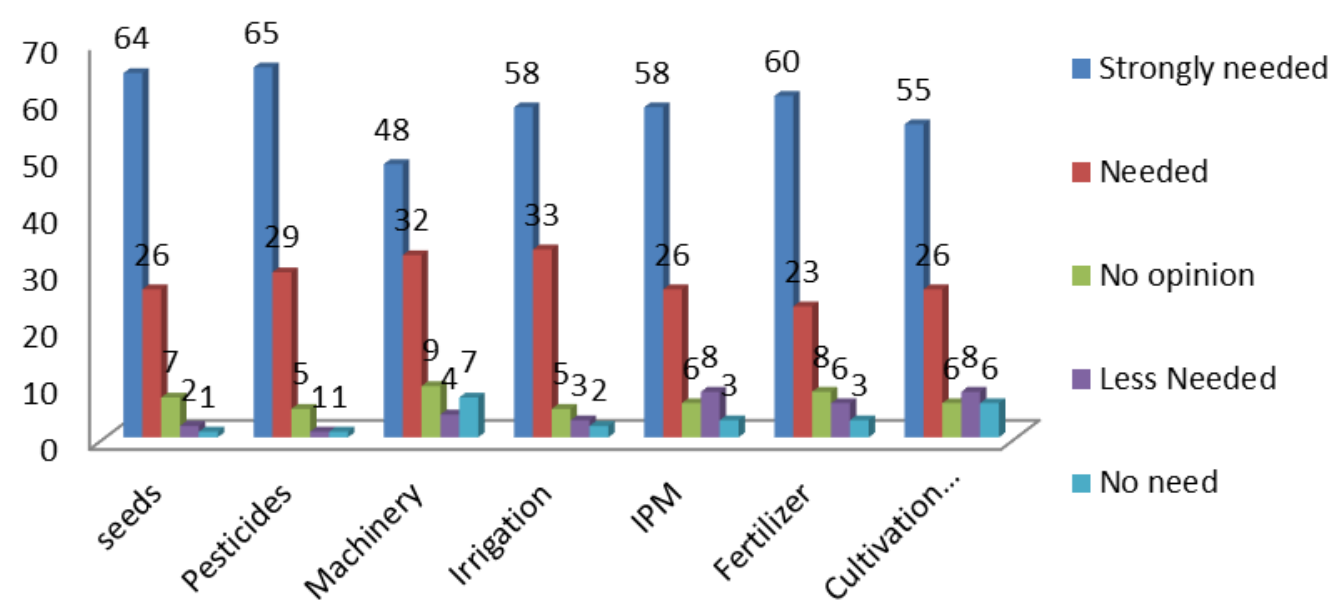

Figure 2: Information needs level by farmers

Other need preferences shown by farmers extended from need to no-need as depicted in Figure 2. Additionally, the results in Table 1 indicate that farmers are aware of the information and the required technology services based on their preference levels.

Table 1: Farmers' information needs level with regard to available technology

Strongly needed

Needed

No opinion

Less Needed

No need

\begin{tabular}{cccc} 
Mean & SD & Min & Max \\
\hline 58 & 5.7 & 48 & 65 \\
27.9 & 3.6 & 23 & 33 \\
6.6 & 1.5 & 5 & 9 \\
4.6 & 2.8 & 1 & 8 \\
3.2 & 2.3 & 1 & 7
\end{tabular}


Creative Commons User License: CC BY-NC-ND

Abstracted by: EBSCOhost, Electronic Journals Service (EJS),

Google Scholar, Journal Seek, Scientific Commons,

Food and Agricultural Organization (FAO), CABI and Scopus
Journal of Agricultural Extension

Vol. 25 (2) April, 2021

ISSN(e): 24086851; ISSN(Print); 1119944X

http://journal.aesonnigeria.org

http://www.ajol.info/index.php/jae

Email: editorinchief@aesonnigeria.org

Farmers' display different behaviors regarding the type of information required, and therefore capitalize on them to reap benefits and maximize rice outputs. From the findings, pesticides, seeds, and fertilizer display a strong relationship concerning farmers' needs. This finding is attributed to many factors such as the prevailing impact of climate change and weather variability which has been always leaving farmers with poor yields. These findings agree with the previous findings of (Kulyakwave et al., 2019). Therefore, due to climate change and weather variability, farmers require reliable agricultural and technological information to increase resilience and adaption levels. More so, accurate information regarding pesticides and herbicides could help to reduce the prevalence of disease and pests, especially during high sunshine and temperature. Similarly, information concerns to fertilizer availability, input prices, and application techniques are crucial to support crop growth as a result of soil erosion. This finding concurs with (Ninan and Makoto, 2017) on their study of building a climate change resilient economy and society. Additionally, among the technical information, the needs behavior was highly shown on the irrigation technology which was close to agricultural machinery. It is notable that, the least responses by the farmers were on no-needs, less needed, and noopinions with regards to all types of technological information. These findings show that all the identified technological information in this study (Figure 2) is of paramount importance to farmers.

\section{Methods of Application for Available Agricultural Technologies}

Figure 3 summarizes the application methods for the information and technology for mean rice yield in kilograms per ha from the study area. Four application methods were rated according to farmers' preferences. These include demonstrations, field exposure, through lectures, advertisement by postal and print media. Among the farmers $60 \%, 22.5 \%, 14.2 \%, 3.3 \%$ identified to prefer demonstration, field exposure, lectures, and print media (Figure 3). 


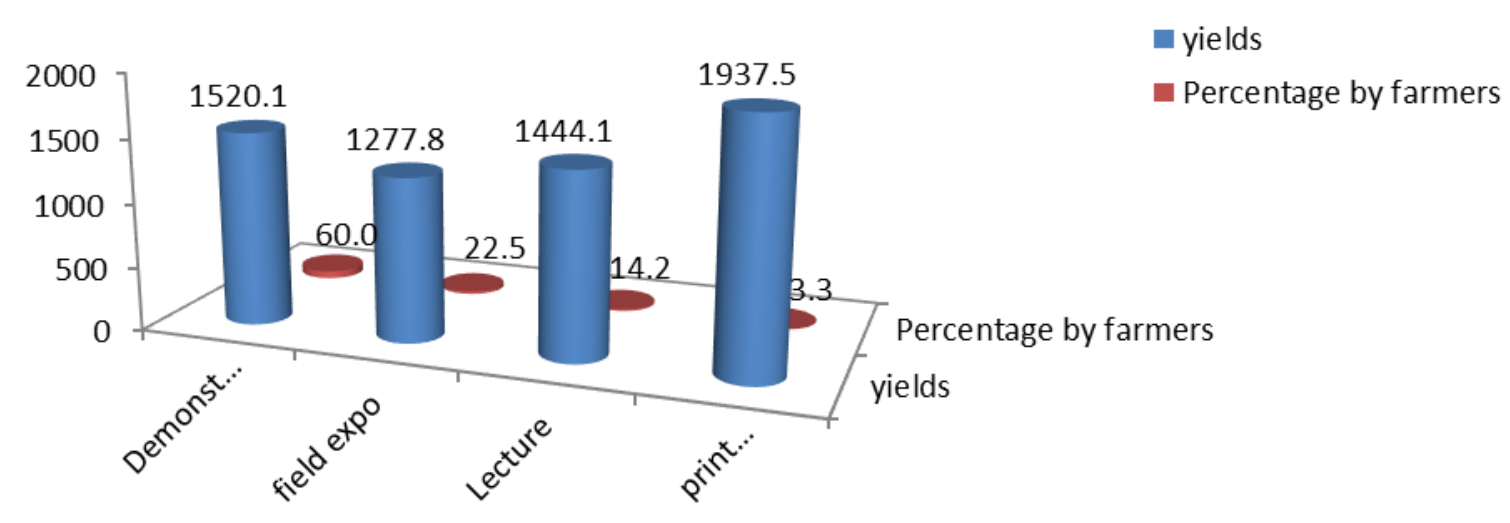

Figure 3: Means and methods for information application

Agricultural extension and technological services dissemination differ from one area to another and depends on the social-culture, economic, and political status of the society. Farmers are exposed to show preferences among the four extensions and technological services delivering. The respondents have shown that the demonstration method is the most method preferred among the others. The majority of farmers expressed that through field demonstrations was easier to capture new ideas through physical interactions with the providing agents. This trend is similar to that of (Burgus and Duysen, 2017: Yaseen, Xu, Yu, and Hassan, 2016). Another method preferred by the farming community next to the demonstration was field visit. However, this method has not gained so much attractiveness because it is expensive in terms of time and financial aspects. It is possible for a smaller group rather than a larger group especially for those with higher or reasonable education, social leaders, retired-farmers or workers, and individuals with good capital (Burgus and Duysen, 2017). The least preferred methods for receiving information by the respondents are the use of lecture and print media. The possible reasons accounted for this could be that the methods are too selective in terms of age, education, exposure, and ownership of electronic devices such as mobiles, television, and radios. 
Creative Commons User License: CC BY-NC-ND

Abstracted by: EBSCOhost, Electronic Journals Service (EJS),

Google Scholar, Journal Seek, Scientific Commons,

Food and Agricultural Organization (FAO), CABI and Scopus

http://eoi.citefactor.org/10.11226/v25i2
Journal of Agricultural Extension

Vol. 25 (2) April, 2021

ISSN(e): 24086851; ISSN(Print); 1119944X

http://journal.aesonnigeria.org

http://www.ajol.info/index.php/jae

Email: editorinchief@aesonnigeria.org

\section{Farmers' Satisfaction on Information Availability}

Figure 4 indicates that farmers expressed their degree of satisfaction about the services provided by different agents. The satisfaction levels stretched from whether a farmer is strongly satisfied, satisfied, no opinion, dissatisfied, and strongly dissatisfied with regarding types of technological services available.

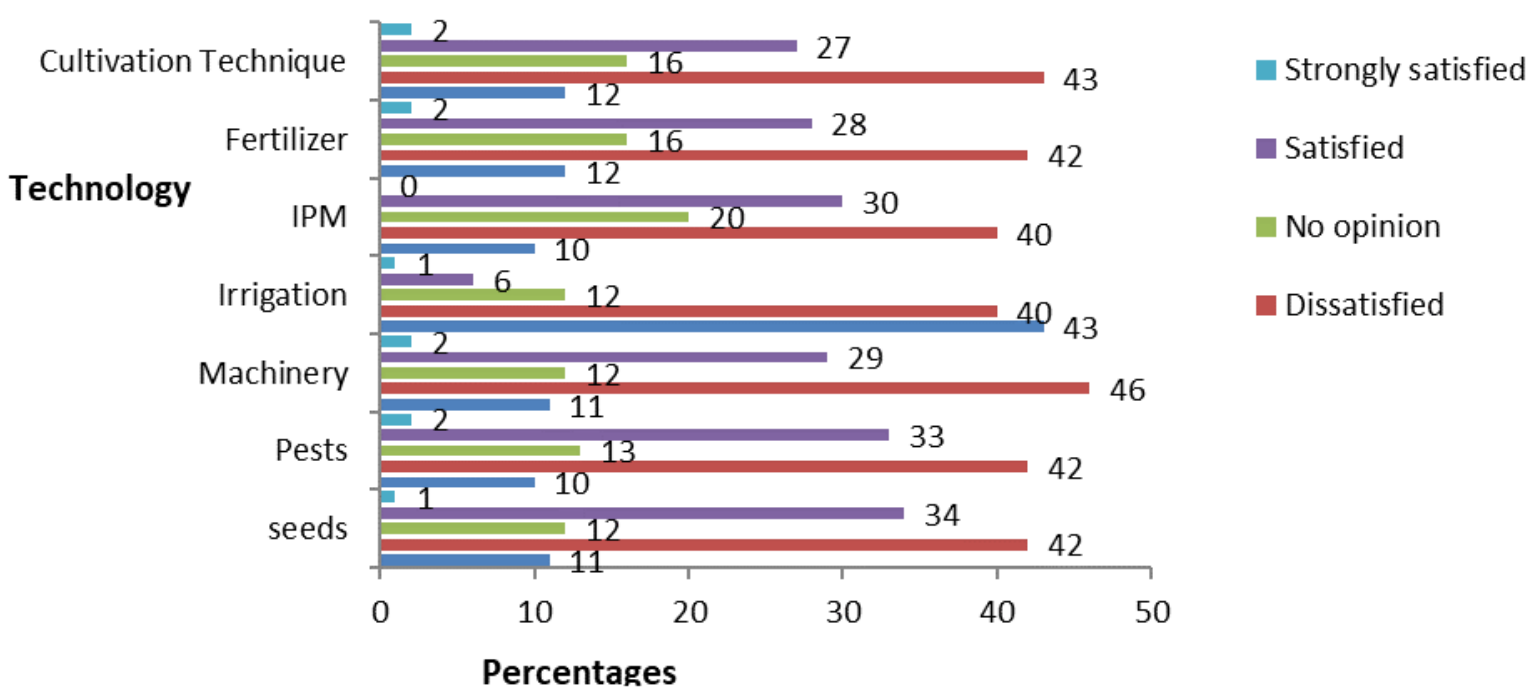

Figure 4: Degree of farmers' satisfaction toward agricultural technological services

These include seeds, pesticides, machinery, irrigation technology, cultivation technology, Integrated Pest Management (IPM), and fertilizer. Furthermore, the degree of satisfaction is shown in terms of percentages for each technology type (Figure 4). Additionally, Table 2 discloses that the majority of farmers as presented in Figure 5 are dissatisfied and satisfied with a score means of 42 and 26 respectively. Other identified responses were strongly dissatisfied, with no opinion, and strongly satisfied with means of $16,15,1.5$ respectively.

\section{Table 2: The results of farmers' satisfaction levels to technology availability}

Dissatisfied

Mean

Satisfied

Strongly Dissatisfied

No Opinion

Strongly Satisfied

\begin{tabular}{cccc} 
Mean & SD & Min & Max \\
\hline 42 & 0.9 & 40 & 46 \\
26 & 4 & 6 & 33 \\
16 & 5.3 & 10 & 43 \\
15 & 1.2 & 12 & 20 \\
1.5 & 0.3 & 0 & 2
\end{tabular}


Creative Commons User License: CC BY-NC-ND

Abstracted by: EBSCOhost, Electronic Journals Service (EJS),

Google Scholar, Journal Seek, Scientific Commons,

Food and Agricultural Organization (FAO), CABI and Scopus
Journal of Agricultural Extension

Vol. 25 (2) April, 2021

ISSN(e): 24086851; ISSN(Print); 1119944X

http://journal.aesonnigeria.org

http://www.ajol.info/index.php/jae

Email: editorinchief@aesonnigeria.org

Farmers feel satisfied with any method provided that is reliably available on time and effective to impact positively the farming operations. Notably, farmers' responses are from strong satisfaction, satisfied, no opinions, and dissatisfaction regarding several farming technologies (Figure 4). The reaction from the farmers illustrates that the majority (Table 2 ) are not satisfied $\left(x^{-}=42\right)$ with the level of agricultural information and technological services given by extension agents. This indicates that demands for the services are high as compared to supply (Misaki and Gaiani, 2016). Additionally, the majority of farmers claimed to receive enough information about irrigation technology. Among the identified challenge for irrigation, implantations are the poor irrigation infrastructures. This finding is similar to what was documented by Sarah et al. (2017) that lack of updated information about the availability of new irrigation technologies, new seed varieties, fertilizers, and agricultural machineries hampered small scale rice farmers to attain their production potentials. However, from the study region only a few communities from the Mbarali District are doing irrigation.

\section{Conclusion and Recommendation}

Different information services including new seed varieties, pesticides, agricultural machineries, irrigation technologies, integrated pest management, and fertilizers are the most required information by the farmers. Also, information concerning technological services was rated least among others due to the lack of farmers' awareness to the type of technology, availability, and applicability. Government should with other stakeholders including non-government institutions that are able to provide reliable and modern agricultural extension services to farmers in the rural areas.

\section{Acknowledgments}

This article was supported by the CAAS Science and Technology Innovation Project (number: CAAS-ASTIP-2018), founded by the Chinese Academy of Agricultural Sciences.

\section{Authors' Contributions}

PDK and XS designed the study. PDK and WY performed the statistical analysis, wrote the protocol. PDK and WY managed the analyses of the study. PDK and SS managed the 
Creative Commons User License: CC BY-NC-ND

Abstracted by: EBSCOhost, Electronic Journals Service (EJS),

Google Scholar, Journal Seek, Scientific Commons,

Food and Agricultural Organization (FAO), CABI and Scopus

http://eoi.citefactor.org/10.11226/v25i2
Journal of Agricultural Extension

Vol. 25 (2) April, 2021

ISSN(e): 24086851; ISSN(Print); 1119944X

http://journal.aesonnigeria.org

http://www.ajol.info/index.php/jae

Email: editorinchief@aesonnigeria.org

literature searches and compiled the manuscript. PDK and MS wrote the first draft of the manuscript. All authors read and approved the final manuscript.

\section{Reference}

Aldosari, F., Saleh, M., Shunaifi, A., Amjad, M., Muddassir, M., and Ali, M. (2017): Farmers' perceptions regarding the use of information and communication technology (ICT) in Khyber Pakhtunkhwa, Northern Pakistan. Journal of the Saudi Society of Agricultural Sciences. https://doi.org/10.1016/j.jssas.2017.05.004.

Ase, A. S. B., Oor, O. F. P., In, F. A., and Ndia, I. (2017). The impact of mobile phone use and IKSL\&\#x0027; ; audio messages on the asset base of poor farmers in Lucknow, India. EJISDC, 79(8), 1-17. https://doi.org/10.1002/j.1681-4835.2017.tb00584.x

Ashraf, S., Hassan, Z. Y., and Ashraf, I. (2019): Dynamics of agricultural extension services in Pakistan: A history of national performance. The Journal of Animal and Plant Sciences, 29(6), 1707-1717.

Asongu, S., and Asongu, N. (2018): The comparative exploration of mobile money services in inclusive development. International Journal of Social Economics, v.45, n.1, p.124139. Available from: https://www.econstor.eu/bitstream/10419/173617/1/agdiwp-17011.pdf

Baig, M. B., Muneer, S. E., Hussain, S. M., Aldosari, F. O., Sciences, A., and Saud, K. (2019): Farmers' level of knowledge on the usage of pesticides and their effects on health and environment in Northern Pakistan. The Journal of Animal and Plant Sciences, 29(6), 1718-1732.

Burgus, S., and Duysen, E. (2017): Identifying topics and dissemination methods for agricultural safety and health messages. Safety, 3(3), 1-12. https://doi.org/10.3390/safety3010003

lliyas, S. (2015): Impact of information technology in agriculture. International Journal of Food, Agriculture and Veterinary Sciences, 4(April), 1-7.

Kansiime, M. K., Alawy, A., Allen, C., Subharwal, M., Jadhav, A., and Parr, M. (2019): Effectiveness of mobile agri-advisory service extension model: Evidence from direct2farm program in India. World development perspectives, 13(February), 25-33. https://doi.org/10.1016/i.wdp.2019.02.007

Khan, N. A., Qijie, G., Ali, S., Shahbaz, B., and Shah, A. A. (2019): Farmers' use of the mobile phone for accessing agricultural information in Pakistan: A case of Punjab province. Ciencia Rural, 2018(49), 1-12. https://doi.org/http://dx.doi.org/10.1590/0103-8478cr20181016 
Creative Commons User License: CC BY-NC-ND

Abstracted by: EBSCOhost, Electronic Journals Service (EJS),

Google Scholar, Journal Seek, Scientific Commons,

Food and Agricultural Organization (FAO), CABI and Scopus

http://eoi.citefactor.org/10.11226/v25i2
Journal of Agricultural Extension

Vol. 25 (2) April, 2021

ISSN(e): 24086851; ISSN(Print); 1119944X

http://journal.aesonnigeria.org

http://www.ajol.info/index.php/jae

Email: editorinchief@aesonnigeria.org

Kulyakwave, P. D., Xu, S., and Yu, W. (2019): Households' characteristics and perceptions of weather variability impact on rice yield: an empirical analysis of small scale farmers in Tanzania. Ciencia Rural, 49(11), 1-13. https://doi.org/eld: empirical analysis... http://dx.doi.org/10.1590/0103-8478cr20190003

Kulyakwave, P. D., Xu, S., and Yu, W. (2019): Rice Farmers' perceptions and indicators for weather variability in Tanzania: What are the obstacles for in situ adaptations? Journal of Physics, 1176(2019), 1-9. https://doi.org/10.1088/1742$\underline{6596 / 1176 / 4 / 042074}$

Misaki, E., and Gaiani, S. (2016): Technology for small scale farmers in Tanzania: A Design Science Research Approach. EJISDC, 76(4), 1-15. https://doi.org/10.1002/j.16814835.2016.tb00538.x

Moshi, A., and Isinika, A. (2016). Climate variability and farm technology adoption decisions among smallholder farmers in Pangani River Basin. Journal of Economics and Sustainable Development, 7(2), 18-24.

Msoffe, G. and Ngulube, P. (2017): 'Utilisation of poultry management information in three rural districts of Tanzania'. South African Journal of Information Management 19(1), a729. https://doi.org/10.4102/sajim.v19i1.729

Muema, E., Mburu, J., Coulibaly, J., and Mutune, J. (2018): Determinants of access and utilisation of seasonal climate information services among smallholder farmers in Makueni County, Kenya. Heliyon, 4(March), e00889. https://doi.org/10.1016/i.heliyon.2018.e00889

Neha, P. (2018): Assessing the farmer's opinion towards usage of mobile phone SMS service: a study of Uttar Pradesh, India. Plant Archives, v.18, n.1, p.507-511. Available from: http://www.plantarchives.org/PDF\%20181/507511\%20(PA3\%204092).pdf.Accessed: Apr. 27, 2018.

Ninan, K.N., and Makoto, I. (2017): Building a climate change resilient economy and society. Edward Elgar Publishing. UK. https://books.google.com/books?id=6ugnDwAAQBAJ.

Sarah, A. W., Alec, Z., Henning, B., Makarius, V. M., Andre, Rooyen and Paiva, M. (2017): An overview of extension use in irrigated agriculture and case studies in southeastern Africa, International Journal of Water Resources Development, 33:5, 755769, https://doi.org/10.1080/07900627.2016.1225570

Schirone, M. (2016): A comparative study of information-seeking behavior and digital information needs of farmers in Turkey and Sweden. International Journal of EBusiness and e-Government Studies, 8(2), 18-33. Retrieved from https://digitalcommons.unl.edu/libphilprac/866 
Creative Commons User License: CC BY-NC-ND

Abstracted by: EBSCOhost, Electronic Journals Service (EJS),

Google Scholar, Journal Seek, Scientific Commons,

Food and Agricultural Organization (FAO), CABI and Scopus

http://eoi.citefactor.org/10.11226/v25i2
Journal of Agricultural Extension

Vol. 25 (2) April, 2021

ISSN(e): 24086851; ISSN(Print); 1119944X

http://journal.aesonnigeria.org

http://www.ajol.info/index.php/jae

Email: editorinchief@aesonnigeria.org

Tanzania Economic Outlook. (2016): The economic review. The story behind numbers. https://www2.deloitte.com/content/dam/Deloitte/tz/Documents/tax/Economic\%200utl ook\%202016\%20TZ.pdf. Accessed on November 7, 2019.

Temba, B. A., Kajuna, F. K., Pango, G. S., and Benard, R. (2016): Accessibility and use of information and communication tools among farmers for improving chicken production in Morogoro municipality, Tanzania. Livestock Research for Rural Development. 28(11). Accessed November 7, 2019, from http://www.Irrd.org/lrrd28/1/temb28011.html

Yaseen, M., Xu, S., Yu, W., and Hassan, S. (2016): Farmers' access to agricultural information sources: Evidences from rural Pakistan. Journal of Agricultural Chemistry and Environment, 5(January), 1-9. https://doi.org/10.4236/jacen.2016.51B003 